\title{
Age Estimation by Ossification at Elbow Joints - A Cross Sectional Study
}

\author{
Vijay Kumar AG', Shivaramu $\mathbf{M g}^{\mathbf{2}}$, Kumar $\mathbf{U}^{3}$, Dr. Vinay $\mathbf{J}^{*}$, Somshekar $\mathrm{S}^{\mathbf{4}}$ \\ ${ }^{1}$ Associate professor, Department of Forensic Medicine \& Toxicology, Adichunchanagiri Institute of Medical \\ Sciences, Adichunchanagiri University, B G Nagara, Nagamangala Taluk, Mandya, Karnataka State, India \\ ${ }^{2}$ Principal and Professor, Department of Forensic Medicine \& Toxicology, Adichunchanagiri Institute of \\ Medical Sciences, Adichunchanagiri University, B G Nagara, Nagamangala Taluk, Mandya, Karnataka State, \\ India \\ ${ }^{3}$ Professor, Department of Forensic Medicine \& Toxicology, Adichunchanagiri Institute of Medical Sciences, \\ Adichunchanagiri University, B G Nagara, Nagamangala Taluk, Mandya, Karnataka State, India \\ ${ }^{4}$ Assistant Professor, Department of Forensic Medicine \& Toxicology, Adichunchanagiri Institute of Medical \\ Sciences, Adichunchanagiri University, B G Nagara, Nagamangala Taluk, Mandya, Karnataka State, India \\ *Corresponding Author: Dr. Vinay J, Assistant professor, Department of Forensic Medicine and \\ Toxicology, Adichunchanagiri Institute of Medical Sciences, Adichunchanagiri University Bg Nagara, \\ Nagamangala Taluk, Mandya District, Karnataka, India. Email: vijay.fmt@ rediffmail.com
}

\begin{abstract}
The first step in ossification of the cartilage is that the cartilage cells, at the point where ossification is commencing and which is termed as an ossification center, enlarge and arrange them in rows. 1 The study was carried out involving 100 school students of age group 14 to 16 years at residential school nearest to the Dept of Forensic Medicine, Adichunchanagiri Institute of Medical Sciences. In 14 years boys, conjoint epiphysis was in Stage 4 union in 4 subjects and Stage 5 union in 20 subjects. In 15 years boys, conjoint epiphysis was in Stage 4 union in 3 subjects and Stage 5 union in 22 subjects. In 14 years boys, medial epicondyle was in Stage 3 union in 21 subjects and Stage 5 union in 4 subjects. In 15 years boys, medial epicondyle was in Stage 3 union in 14 subjects and Stage 5 union in 9 subjects. In 14 years boys, proximal end of radius was in Stage 3 union in 14 subjects and Stage 5 union in 10 subjects. In 15 years boys, proximal end of radius was in Stage 3 union in 13 subjects and Stage 5 union in 8 subjects. In 14 years boys, proximal end of ulna was in Stage 3 union in 12 subjects and Stage 5 union in 10 subjects. In 15 years boys, proximal end of ulna was in Stage 3 union in 6 subjects and Stage 5 union in 9 subjects.
\end{abstract}

Keywords: Age Estimation, Ossification, Elbow Joints

\section{INTRODUCTION}

The first step in ossification of the cartilage is that the cartilage cells, at the point where ossification is commencing and which is termed as an ossification center, enlarge and arrange them in rows. [1]

The matrix in which they are imbedded increases in quantity, so that the cells become further separated from each other.

A deposit of calcareous material now takes place in this matrix, between the rows of cells, so that they become separated from each other by longitudinal columns of calcified matrix, presenting a granular and opaque appearance. Here and there the matrix between two cells of the same row also becomes calcified, and transverse bars of calcified substance stretch across from one calcareous column to another. Thus there are longitudinal groups of the cartilage cells enclosed in oblong cavities, the walls of which are formed of calcified matrix which cuts off all nutrition from the cells; the cells, in consequence, atrophy, leaving spaces called the primary areolae.

Age estimation in living individuals is a relatively recent area of applied research within the forensic medicine. Its value and importance as an assessment tool has risen exponentially as the needs for an informed opinion on the age of an individual have assumed increasing importance for the assessment of both criminal culpability and legal/social categorization. Age is an important classifier in most cultural and judicial hierarchies, and the absence of credible legal documentation often demands that 
authorities must seek the expertise of the clinician for guidance and assistance in this regard.

In developing countries like India, because of illiteracy and ignorance regarding the importance of official records like birth and death, vast majority of population fail to give information of such vital events to the appropriate authorities entitled with these jobs. This causes paucity in such information when needed in a medico legal case.

Determination of age is even more important in cases, where only skeletal remains are available for analysis, due to attempt made to dispose the body by mutilation, by dismemberment, by the use of corrosives, by the action of fire or in cases where murder was committed long ago. It is necessary sometimes to identify persons in mass disasters like earth quakes, floods, rail and air accidents, bomb explosions etc.

Objective: To study the status of ossification centers at Elbow and Wrist joints

\section{Methodology}

\subsection{Source of Data}

The study was carried out involving 100 school students of age group 14 to 16 years at residential school nearest to the Dept of Forensic Medicine, Adichunchanagiri Institute of Medical Sciences.

Study period: January to June 2018

Table2: Ossification status around elbow joint

\begin{tabular}{|c|c|c|c|}
\hline Ossification Status & 14 Years Boys & 15 Years Boys & Total \\
\hline \multicolumn{2}{|c|}{ Conjoint epiphysis } \\
\hline Stage 0 & 00 & 00 & 00 \\
\hline Stage 1 & 00 & 00 & 00 \\
\hline Stage 2 & 00 & 00 & 00 \\
\hline Stage 3 & 01 & 00 & 01 \\
\hline Stage 4 & 04 & 03 & 07 \\
\hline Stage 5 & 20 & 22 & 42 \\
\hline Total & 25 & 25 & 50 \\
\hline \multicolumn{5}{|c|}{ Medial epicondyle } \\
\hline Stage 0 & 00 & 00 & 00 \\
\hline Stage 1 & 00 & 00 & 00 \\
\hline Stage 2 & 00 & 02 & 02 \\
\hline Stage 3 & 21 & 14 & 35 \\
\hline Stage 4 & 00 & 00 & 00 \\
\hline Stage 5 & 04 & 25 & 13 \\
\hline Total & 25 & 09 & 50 \\
\hline Stage 0 & 00 & 00 & 00 \\
\hline
\end{tabular}

\subsection{Inclusion Criteria}

- Healthy, normal students between age group who have completed 14 years but not completed 16 years of age.

- Subjects who had documentary evidence of age in the form of birth certificate issued by Municipal authority and/ or school records.

\subsection{Exclusion Criteria}

- Subjects with skeletal deformity, disease, malformation or injury.

- Subjects with severe malnutrition, endocrinal disorders or chronic illness.

- Sampling Method: - Simple Random Sampling.

\subsection{Radiological Examination}

The subjects were subjected to the X-ray examination of the elbow joints of right hand at the Department of Radio diagnosis and Imaging. The X-rays of the right Elbow joints were taken in both antero- posterior (AP) view and lateral view.

\section{Results}

Table1: Age wise distribution of study subjects

\begin{tabular}{|c|c|}
\hline Age group & Number \\
\hline 14 years & 25 \\
\hline 15 Years & 25 \\
\hline Total & $\mathbf{5 0}$ \\
\hline
\end{tabular}

Above table depicts the age wise distribution of the study subjects. For the purpose of comparison and analysis, equal number of students in each age group of 14 years (14-15 years) and 15 years (15-16 years) were selected for the present study. 


\begin{tabular}{|c|c|c|c|}
\hline \multicolumn{3}{|c|}{} & 00 \\
\hline Stage 1 & 00 & 01 & 00 \\
\hline Stage 2 & 00 & 13 & 01 \\
\hline Stage 3 & 14 & 03 & 04 \\
\hline Stage 4 & 01 & 08 & 18 \\
\hline Stage 5 & 10 & 25 & 50 \\
\hline Total & 25 & 00 & 00 \\
\hline \multicolumn{2}{|c|}{ Proximal end of Ulna } & 02 \\
\hline Stage 0 & 00 & 01 & 05 \\
\hline Stage 1 & 02 & 03 & 18 \\
\hline Stage 2 & 02 & 06 & 07 \\
\hline Stage 3 & 12 & 06 & 19 \\
\hline Stage 4 & 01 & 09 & 50 \\
\hline Stage 5 & 10 & 25 & \\
\hline Total & 25 & & \\
\hline
\end{tabular}

In 14 years boys, conjoint epiphysis was in Stage 4 union in 4 subjects and Stage 5 union in 20 subjects. In 15 years boys, conjoint epiphysis was in Stage 4 union in 3 subjects and Stage 5 union in 22 subjects.

In 14 years boys, medial epicondyle was in Stage 3 union in 21 subjects and Stage 5 union in 4 subjects. In 15 years boys, medial epicondyle was in Stage 3 union in 14 subjects and Stage 5 union in 9 subjects.

In 14 years boys, proximal end of radius was in Stage 3 union in 14 subjects and Stage 5 union in 10 subjects. In 15 years boys, proximal end of radius was in Stage 3 union in 13 subjects and Stage 5 union in 8 subjects.

In 14 years boys, proximal end of ulna was in Stage 3 union in 12 subjects and Stage 5 union in 10 subjects. In 15 years boys, proximal end of ulna was in Stage 3 union in 6 subjects and Stage 5 union in 9 subjects.

\section{DISCUSSION}

In 14 years boys, conjoint epiphysis was in Stage 4 union in 4 subjects and Stage 5 union in 20 subjects. In 15 years boys, conjoint epiphysis was in Stage 4 union in 3 subjects and Stage 5 union in 22 subjects. Thus complete union in this area at conjoint epiphyses is more likely to occur in the age group of 15-16 years. This finding was consistent with the other studies done in India by Lal and Nat (1934) [2] in Lucknow boys, Galstaun (1937) [3] in Bengal, Kothari (1974) [4] in Marwar, Jain S (1999) [5] in Jaipur, Bhise (2010) [6] in Mumbai and Potdar AB (2012) [7] in Bagalkot.

In 14 years boys, medial epicondyle was in Stage 3 union in 21 subjects and Stage 5 union in 4 subjects. In 15 years boys, medial epicondyle was in Stage 3 union in 14 subjects and Stage 5 union in 9 subjects. This observation is consistent with the studies done by Lal and Nat (1934) [2] in Lucknow, Pillai (1936) [8] in Madras, Galstaun (1937) [3] in Bengal, Kothari (1974) [4] in Marwar, Jain S (1999) [5] in Jaipur, Bhise (2010) [6] in Mumbai, and Potdar AB (2012)7 in Bagalkot.

In 14 years boys, proximal end of radius was in Stage 3 union in 14 subjects and Stage 5 union in 10 subjects. In 15 years boys, proximal end of radius was in Stage 3 union in 13 subjects and Stage 5 union in 8 subjects. Considering other Indian studies, our observations are consistent with the studies by Lal and Nat (1934) [2] in Lucknow, Pillai (1936) [8] in Madras, Galstaun (1937) [3] in Bengal, Kothari (1974) [4] in Marwar, and Potdar AB (2012) [7] in Bagalkot except for study done by Jain S (1999)5 in Jaipur who observed epiphyseal union at proximal end of radius during 15-16 years.

In 14 years boys, proximal end of ulna was in Stage 3 union in 12 subjects and Stage 5 union in 10 subjects. In 15 years boys, proximal end of ulna was in Stage 3 union in 6 subjects and Stage 5 union in 9 subjects. This observation is consistent with other Indian studies done by Lal and Nat (1934) [2] in Lucknow, Pillai (1936) [8] in Madras, Galstaun (1937) [3] in Bengal, Kothari (1974) [4] in Marwar, Bhise (2010) [6] in Mumbai and Potdar AB (2012)7 in Bagalkot.

\section{CONClusion}

Our critical literature review reveals that there is no standard method for bone age assessment. The most commonly used and extensively developed methods use Elbow radiographs in children under 18 years. Also, some methods are considered applicable to

Children of certain populations whereas they do not conform to the growth pattern of children in other geographic location. 


\section{REFERENCES}

[1] Gray and Spitzka (1910), page 44

[2] Lal R, Nat BS. Age of epiphyseal union at the elbow and wrist joints among Indians. Indian Journal of Medical Research 1934; 21(4):p.683-9.

[3] Galstaun G. A study of ossification as observed in Indian subjects. Indian Journal of Medical Research July 1937; 25:p.267-324.

[4] Kothari DR. Age of epiphyseal union at elbow and wrist joints in Marwar region of Rajasthan. Journal of Indian Medical Association 1974 Oct; 63(8):p.252-6.

[5] Jain S. Estimation of age from 13 to 21 years.
JFMT 1999 Jan-June; 16(1):p.27-30.

[6] Bhise. A roentgenographic study of age related skeletal maturity among cases referred to a medical college of Mumbai. M.D. Thesis submitted to MUHS, 2010.

[7] Potdar AB. Status of ossification at elbow joint, dental eruption and secondary sexual characteristics in school children of 14-16 years age in Bagalkot city. M.D. Thesis submitted to RGUHS, 2012.

[8] Pillai MJS. The study of epiphyseal union for determining the age of South Indians. Indian of Journal Medical Research 1936; 23:p.1015-7.

Citation: Vijay Kumar AG, Shivaramu Mg, Kumar U, Dr. Vinay J, Somshekar S. Age Estimation by Ossification at Elbow Joints -A Cross Sectional Study. ARC Journal of Forensic Science. 2019 4(2):6-9. http://dx.doi.org/10.20431/2456-0049. 0402002

Copyright: (C) 2019 Authors. This is an open-access article distributed under the terms of the Creative Commons Attribution License, which permits unrestricted use, distribution, and reproduction in any medium, provided the original author and source are credited. 